\title{
RISK MITIGATION FOR SMALL AND MEDIUM-SIZED ENTERPRISES (SMES) IN THE MIDDLE OF VOLATILITY IN THE WORLD'S ECONOMY CONDITION
}

\author{
Gresika Bunga Sylvana \\ MS in Risk Management Student in Queens College, City University of New York, USA \\ gresika.bungasylvana8I@qmail.cuny.edu or data.gresikabunga@gmail.com
}

\begin{abstract}
Indonesia's economic growth in the first quarter of 2020 of $2.97 \%$ was released by the Central Statistics Agency (BPS). It is undeniable, that number is the lowest growth rate in the last 19 years. We understand that the economic disruption caused by the COVID-19 pandemic did occur in various parts of the world. A significant economic slowdown is a big task for many national leaders. Some world economic experts even mention that the disruption of the economy due to this pandemic can resemble the effects of the Great Depression of 1930 ago. If we review the impact of the COVID19 pandemic which has caused extraordinary disruption in the economic field, it is seen that Micro, Small, and Medium Enterprises (MSMEs) are a sector that is quite severe. Basically, the concept of risk management is not commonly used in SMEs business processes. This is because, in general, the resources owned by SMEs are quite limited. However, in this paper I want to illustrate at least there are simple concepts that can be applied by SMEs.
\end{abstract}

Keywords: Risk management, risk management, Small and Medium-sized Enterprises, general concept of risk

Received 14 August 2020 Accepted 6 February 2021

\section{INTRODUCTION}

The discourse on the global recession, which will certainly have an impact on economic activity, is increasingly inevitable. World economists such as Chetan Ahya (Morgan Stanley) and Jan Hatzius (Goldman Sachs) compactly predict economic slowdown. Hatzius believes global economic growth is at the point of $1.25 \%$ throughout 2020. More conservative, Ahya even projects global economic growth to be in the range of $0.9 \%$.

Disruption of the world economy becomes a challenge to complete the discourse of a global recession that has seen its symptoms in recent years. When this article was compiled, the phenomenon of the covid19 virus epidemic was ravaging. The economic effects of the pandemic are incredibly serious. The algorithm of the normal supply of goods becomes difficult to read. Panic buying occurs even in cities that are considered to have the most logical consumers such as New York, London, and other large cities.

The nation's best economists strive to measure and prepare the best compass for the threequarter equivalent of the National Long-Term Development Plan 2005-2025 which targets the goals of increasing economic growth and reducing inequality. One of the paths taken is to draw valuable experiences from the past.

1998 was a valuable learning year for Indonesia. Amid the collapse of the country's economic conditions, MSMEs have proven to be able to survive. Become the backbone of economic growth. Utilization of local resources, dependence on loans in the banking sector is two of the various logical factors in the strength of this form of business in the midst of a crisis. 
It's not too much if today, where the world is faced with the challenges of a global recession, we place the hope that SMEs will become a buffer zone..

\section{RESEARCH METHOD}

This paper uses a qualitative approach that focuses on elaborating ideas to provide input on the simple things that SMEs can do to maximize performance amidst the impact of a pandemic.

\section{DISCUSSION}

Basically, the concept of risk management is not commonly used in SMEs business processes. This is because, in general, the resources owned by SMEs are quite limited. In general, there are several things that can be considered. First, good financial management is one of the keys to SMEs in maintaining persistent and credible business growth. Initial capital management, expenditure flows, and professionalism in profit play are key factors in maintaining the SME's business ecosystem. In addition, ensuring that the relay in the operational chain runs smoothly is also important. In terms of structure, the clear division of functions and responsibilities between fields within the SMEs will certainly facilitate the ongoing business processes. Likewise, from the point of view of the flow of goods or services, an organized system will certainly help SMEs to be able to deliver products well to the user. Finally, digital platform utilization for marketing is also important. Not limited to the idea of innovation related to products or services produced, the right strategy in marketing is also a crucial thing to note. In this digital age, domestic SMEs are increasingly looking at utilizing various online platforms that are easily accessible to the market as targetted. In this part, we would like to discuss simple concepts that can be applied by SMEs as follows:

\section{Mitigation 1: Make Financial Projection as a Base}

In starting a business, having good financial planning is a very important thing. Lack of attention to financial flows in our business can make a lot of important things go wrong. One example might be a messy payment plan, mistrust of the supplier, or even the customer. If this is not immediately addressed, it is not impossible that the business we have built will become so serious that it will end up bankrupt. It is very important to have financial projections in our business. Estimates of cash flows that have been prepared in detail will help us to see which times of the year our business will have a surplus, and which months can produce deficits. Up and down in business is certainly a common thing. With this understanding, we will be much better prepared. In addition, cash flow projections can help us to identify potential problems that may exist in our business.

Adequacy of cash owned by a business can be a problem for SMEs. Of course, having an accurate estimate can help us find potential failures early. So that these can be signals that help to make the right decision. Appropriate decision making can help us to prevent or reduce the impact of this. Some examples of which are based on these signals may be that we can take steps such as increasing debt collection or making invoices earlier to maintain the cash adequacy that our business has. If we have an estimated cash shortage through recording cash flow planning, it is likely that the ability to fund product marketing costs and pay employees is better because things are much more organized. It cannot be denied, access to bank funding is something that is often complained of by SMEs. Nowadays, increasing the confidence of the Bank to provide access to funding becomes important. When we want to apply for access to funding, the Bank will definitely want to see our financial forecasts. This they do to be able to estimate the future ability of our business to repay loans that they provide.

Estimated cash flow that our business has at least must contain an estimate of cash income within a certain period, one month, or one year for example. On the other hand, we must also be able to convince how much cash, our business cash output in the same time period. 


\section{Mitigation 2: Not Relying on One Capital Access}

As we discussed earlier, access to MSME capital is important. Actually, access to capital for MSMEs is not merely a matter of lending to financial institutions such as banks. There are many other ways that are also important and interesting to go to. Let's look at one by one the detailed discussion as follows.

\subsection{Borrow money from banks}

Access to finance from banks is indeed one of the topics that are excellent for MSMEs. The goals range from wanting to develop a business, executing a business idea, to "digging a manhole cover" or closing a business loan that was previously obtained.

As we know, for the last few years the Indonesian Government has been actively promoting the Entrepreneurship program. This is certainly not only limited to young people or millennials but also the whole society across ages. The government has also conducted many programs to be able to fertilize the seeds of entrepreneurial desires in the country. Some of these include holding seminars, workshops, and making it easier for people to access banking capital.

Bankable itself is an English term with the abbreviation "Bank Ability". That is, bankable is if we are 'Customers who meet the Bank's requirements'. If we as business owners need a credit loan, Bankable can mean that we can meet the Bank's requirements to get business credit. Likewise, vice versa, if we are unable to meet the required requirements, then we are included in Unbankable customers.

The Bank itself will provide loans to businesses that they deem appropriate to receive credit from banks. Indeed, each bank has its own requirements in determining the eligibility of a business to get loan access. But in general, the Account Officer (AO) will consider the business with the following conditions:

1. Legal business, which means the business is intended to run a business that is not contrary to the laws or norms prevailing in Indonesia

2. Business has been running for at least one year. The business also need to have good conditioan as captured by some indicators, as follows:
a. Technical implementation of the business
b. Business benefits for the surrounding community
c. The operating profit and loss flow
d. Business Potential going forward
e. The condition of the business environment
f. How does management manage business

If the Bank sees that a business has fulfilled the two requirements above, a 5C's of Credit analysis will be conducted.

1. Character

They see our character through the banking track record that we have. Our track record as bank debtors or consumers in the past will be seen. Banks can see it through the BI Checking Debtor Information System (SID) / SLIK OJK which can be viewed at Bank Indonesia. The Debtor Information System (BI Checking / SLIK OJK) has data related to our status as debtors. In the past, have we been bankers who were obedient and obedient in paying our banking obligations? Through this OJK BI Checking / SLIK, our status is classified as:

a. Collectibility 1 (Current): the current debtor pays principal and interest debt

b. Collectibility 2 (Special Mention or DPK): the debtor is in arrears in payment within 1-2 credit periods.

c. Collectibility 3 (Non-Current): debtors are in arrears within 3 to 6 months

d. Collectibility 4 (Doubtful): the debtor still does not pay the loan until after the specified time.

e. Collectibility 5 (Bad Credit): the debtor has bad credit that is not paid, and does not have the good faith to pay the loan 
Now, to be able to receive loans from banks, usually, the priority is for customers who are in collectibility 1 . If we have a collectibility status of 2 to 5 , we should resolve our problems so that we can receive loans again in the future.

2. Business Capacity

In looking at business capacity, the Bank will conduct a survey. What is our capacity to run a business? How much loan can we propose? Does our business have the capacity to grow? Will we be able to pay the loan installments provided? If all of these questions can be answered with good criteria, of course, our business capacity is not in doubt.

3. Capital

To see the capital side, the Bank will try to see how the financial condition of our business. This includes how much profit and loss of cash flow and so forth.

4. Condition

The condition referred to at this point is an analysis of whether or not we will actually use the funds for business development. In addition, they will also see whether the funds we submit are indeed in accordance with our needs and ability to pay debts.

5. Collateral Collateral

To be able to minimize bad loans, the bank will use collateral as a form of anticipation. This risk requires the Bank to almost all of its debtors. However, of course, the most important thing is for debtors who experience collectibility 2 to 5 . But usually any type of collectability, the Bank is still required to anticipate these risks by asking us to provide adequate collateral. Some that can be collateralized include:
a. Land/building ownership certificate
b. Vehicle ownership certificate
c. Other assets

\subsection{Attract investors}

It is not a new thing that is running a business, we will not always succeed. There are times when the phases in our business go up and down. This can be caused by many things, two of which are the increase in existing competitors and limited venture capital. On the other hand, there are many prospective business people who have creative ideas to start a business. Basically, these ideas can run smoothly if they can get capital from other people who have capital. Furthermore, people who have the capital and are ready to become partners by depositing their capital in our business are called investors. These investors can be individuals or institutions. However, finding an investor is not as easy as turning the palm of the hand. We need to pay attention to several things so that our business can get an investor who is interested in investing their capital. What do we need to do to convince investors that our business is worth investing in?
a. Following the UMKM business exhibition
b. Participating in the business idea competition
c. Submitting a business idea proposal
d. Make Short and Long Term Business Strategies
e. Make a Business Potential Analysis
f. Tidy up the Business Balance Report

Submitting a business idea proposal, making a short and long term business strategy, and analyzing business potential may be things that are considered normal and have been done by many SMEs. However, did we know that in addition to these three things, to expand networking and improve business acumen, we also need to take part in exhibitions and competitions in the business field?

Participating in exhibitions and competitions in the business field also includes ways we can go to find investors and get capital. In the exhibition and competition, there were many investors present. They usually come to see business concepts. Their simple language is usually "shopping for business ideas" that are interesting. Business ideas that are considered to have 
good opportunities in the future could be "invited" by investors to be able to invest their capital for the business.

Each of us as business people certainly hopes that the business we run can grow. It is undeniable, additional business capital is an important factor to be able to achieve it. If we are looking for an investor, we certainly need to make the right business strategy in developing a business. Prospective investors usually always focus to see what strategies we use. A neat, reliable business strategy will reflect great business prospects in the future.

Finally, what we need to do is tidy up our business balance sheet. A balance sheet is a form of financial statements, we will discuss the details in the next section in this book. If an investor has decided to agree to invest in our business, the investor will basically expect to get profits from the business later. Of course, they will consider carefully the potential for financial benefits and what they might get. In considering the potential gains and losses, they will observe the company's cash flow through the balance sheet. Therefore, before showing business ideas to investors, it is better if we tidy up the balance sheet. We can make a neat balance sheet with separate, detailed accounts of cash, business assets, and debt/liability.

\section{Mitigation 3: Periodic Financial Statements}

A good business certainly must have a neat and sustainable financial record. The contents of course are a summary of every transaction that occurs. Basically, financial records are used as a medium to report transactions that occur within a certain time period. The length of the short term referred to can be adjusted to our needs, can be daily, weekly, or monthly. The report is a reference that we can hold to be able to see the condition of the business that we are running. The importance of a record can also aim to avoid things that are not desirable. Many MSMEs often forget the importance of these financial statements. Busy, no time, not important, or confused about how to make it into many classic reasons that are conveyed. As our business grows and ultimately requires additional capital, financial statements are also increasingly important. When we want to submit a loan to the bank, the financial statements will also be seen by the banks.

Basically, making business financial statements can be self-taught. So whatever our educational background, as long as there is a will, of course, we will be able to do it.

3.1. Types of Financial Statements

First, let's study the types of financial statements. There are several types of financial statements. The purpose of each type of financial statement also varies.

a. Income statement

The income statement is an important report for us to compile. Almost all business entities, both of which have a large scale or must have an income statement, are no exception to us as SMEs. Basically, the income statement is a piece of information that shows how our business conditions are running. The income statement is made in a certain period. Usually, the periods used are monthly, semester, or yearly.

The function of the income statement is to find out whether the business loss or profit in the period. If expenses are greater than income, simply, we can see that the business can be said to be a loss, but if what happens is the opposite, then it can be said that the business we run is in a profit.

b. Statement of changes in capital

Capital change report is a type of report that shows the amount of capital used in our business. This capital includes all capital in the form of cash or other assets that we use to establish and also conduct business operations. Any capital changes that occur in the middle of the period of doing business must also be noted and included in this report. As far as possible not only include the nominal amount, but also additional information to explain why there is a change or where the source is. 


\section{c. Balance Sheet Report}

Basically, the balance sheet is an important report to be able to show the condition of the company in a certain period, especially in terms of assets, liabilities, and capital. The condition of the balance sheet includes assets owned, debts that need to be paid off in the coming period, and how much capital the company has in the period.

d. Cash flow statement

No less important reports that must exist in a business that is the cash flow statement. Statements of cash flows as a depiction of where business capital is used, and where the company's funds come from, and how much money is obtained from investors. In short, the cash flow statement as a hint of funds in and funds out of the business that you are running. In accounting terms more often called cash flow statements with the term cash flow.

\section{CONCLUSION}

It is undeniable that at present, collaboration of various sectors is the key to accelerating economic recovery. Multi-sector cooperation needs to be opened as wide as possible with various parties. Of course, cooperation is carried out with the principles of transparency and accountability. The strategy is also a key to equitable aid, given the population of MSMEs in Indonesia, which reaches around 64 million. If we review the impact of the COVID-19 pandemic which has caused extraordinary disruption in the economic field, it is seen that SMEs are a sector that is quite severe. Implementing some basic and simple mitigations as discussed in this paper is at least an initial step that can be implemented.

\section{REFERENCES}

[1] Christopher Condon dan Bloomberg, Morgan Stanley and Goldman Sachs Declare Global Recession Underway, https://fortune.com/2020/03/17/morgan-stanley-and-goldmansachs-declare-global-recession/, accessed March 20

[2] Falkner, Eva \& Hiebl, Martin. (2015). Risk management in SMEs: a systematic review of available evidence. The Journal of Risk Finance. 16. 122-144. 10.1108/JRF-06-2014-0079.

[3] Jones, Ossie. (2007). Managing SMEs. International Journal of Entrepreneurial Behavior \& Research. 13. 10.1108/ijebr.2007.16013baa.001.

[4] Kementerian Koperasi dan Usaha Kecil dan Menengah Repulik Indonesia, http://www.depkop.go.id/data-umkm, accessed July $8^{\text {th }}, 2020$

[5] Badan Pusat Statistik, bps.go.id/subject/35/usaha-mikro-kecil.html, accessed July 1 ${ }^{\text {st }}, 2020$ 